\title{
Preparation and Characterization of Nanocrystalline Cerium (IV) Oxide and Doped Cerium (IV) Oxide, $\mathrm{Ce}_{1-\mathrm{x}-\mathrm{y}} \mathrm{Mg}_{\mathrm{x}} \mathrm{Zr}_{\mathrm{y}} \mathrm{O}_{2-\delta}$
}

\author{
L. Tashmim ${ }^{1}$, T. Debnath ${ }^{1 *}$, C. H. Rüscher ${ }^{2}$, A. Hussain ${ }^{1,3}$ \\ ${ }^{1}$ Department of Chemistry, University of Dhaka, Dhaka, Bangladesh \\ ${ }^{2}$ Institute of Mineralogy, Leibniz University of Hannover, Hannover, Germany \\ ${ }^{3}$ Centre for Advanced Research in Sciences, University of Dhaka, Dhaka, Bangladesh
}

Received 5 May 2014, accepted in final revised form 18 March 2015

\begin{abstract}
Nanocrystalline cerium (IV) oxide is a technologically important material due to its high oxygen storage capacity, oxygen ionic conductivity and thermal stability. In this paper we report preparation of nanocrystalline $\mathrm{CeO}_{2}$ using glycerin nitrate method, where the precursor obtained from the mixture of cerium nitrate and glycerin were calcined at temperatures ranging from $200^{\circ} \mathrm{C}$ to $800^{\circ} \mathrm{C}$ in steps of $100^{\circ} \mathrm{C}$ in a muffle furnace. Attempts were also made to prepare nanocrystalline cerium (IV) oxide doped with both $\mathrm{Mg}$ and $\mathrm{Zr}$ using the same method. The calcined specimens were characterized using XRD, FTIR and $\mathrm{SEM} / \mathrm{EDX}$ analyses. The influence of the calcination temperature on the cubic phase formation and its consequent effect on the crystallite size of the prepared $\mathrm{CeO}_{2}$ were studied and interpreted. The crystallite sizes calculated from XRD data using Scherrer formula reveal that the phases are nanocrystals, which was further supported by SEM photograph. The apparent activation energy for crystalline coarsening is found to be very low (26.8 $\mathrm{kJmol}^{-1}$ ) for this precursor compared to reported data. XRD data and also EDX analysis shows that both $\mathrm{Mg}$ and $\mathrm{Zr}$ could also be doped in $\mathrm{CeO}_{2}$ upto a certain composition, $\mathrm{Ce}_{1-\mathrm{x}-\mathrm{y}} \mathrm{Mg}_{\mathrm{x}} \mathrm{Zr}_{\mathrm{y}} \mathrm{O}_{2-\delta}(\mathrm{x}=0.05, \mathrm{y}=0.05)$.
\end{abstract}

Keywords: Ceria; Zirconia; Magnesium oxide; Oxygen storage capacity; Nanocrystal.

C) 2015 JSR Publications. ISSN: 2070-0237 (Print); 2070-0245 (Online). All rights reserved. doi: http://dx.doi.org/10.3329/jsr.v7i1-2.18798

J. Sci. Res. 7 (1-2), 55-63 (2015)

\section{Introduction}

Cerium (IV) oxide, also called ceria $\left(\mathrm{CeO}_{2}\right)$ is one of the most interesting materials of rare earth family and has received more attention to researchers due to its multidimensional applications. Major potential applications of $\mathrm{CeO}_{2}$ are ultraviolet radiation absorbent [1], catalytic support or promoter [2], oxygen ion conductor in solid oxide fuel cells (SOFCs) [3], gas sensor [4], hybrid solar cells [5], $\mathrm{H}_{2} \mathrm{~S}$ removal [6], luminescent materials for

* Corresponding author: debnath@du.ac.bd 
violet/blue fluorescence [7], water gas shift reaction, oxidative dehydrogenation [8] etc. $\mathrm{CeO}_{2}$ can be applied in these fields due to its structural and chemical properties such as oxygen storage capacity, high surface area, thermal stability, high hardness index and its reactivity [9]. Oxygen storage capacity of ceria can be explained by switching between $\mathrm{Ce}^{4+}$ and $\mathrm{Ce}^{3+}$ depending on ambient oxygen partial pressure with generation of lattice defect (oxygen vacancy). These properties of ceria can be further enhanced via doping, i.e. partial substitution of cerium by other cations in its crystal lattice to create vacancies, and via preparing nanocrystals to create surface crystal defects for more active sites [1012]. This offers a great opportunity to control the activity and selectivity of oxide catalysts with the aid of innovative nanofabrication techniques. Shapovalov et al. [13] reported that bonds between lattice oxygen and metal atoms in oxide are significantly weakened by the presence of dopants and hence the doped $\mathrm{CeO}_{2}$ surfaces, e.g., (111) plane, become much more active. Several papers have been published about doped $\mathrm{CeO}_{2}$ with various cationsdopants, such as $\mathrm{Ca}, \mathrm{Al}, \mathrm{Zr}, \mathrm{Nd}, \mathrm{Pb}, \mathrm{Mn}, \mathrm{Mg}, \mathrm{Cu}, \mathrm{Zn}, \mathrm{Co}, \mathrm{Y}, \mathrm{Ba}$ and $\mathrm{Sr}$ [14-28].

Literature survey shows that nanocrystalline ceria have been prepared by means of a variety of methods such as sol-gel process [29], hydrothermal or solvothermal synthesis [30, 31], micro-emulsion [32], co-precipitation [33, 34], conventional solid state method, flow method [35], microwave hydrothermal method [36], sonochemical synthesis [37], thermal decomposition [38], spray pyrolysis [39] etc. These methods operate mainly on high pressure, salt-solvent mediated high temperature or surface capping agent and the sizes of ceria particles are relatively large. Therefore, search for a simple approach for low-cost, large-scale, controlled growth of ceria nanoparticles at ambient pressure seems to be important. Here we report preparation of nanocrystalline cerium (IV) oxide by using glycerin nitrate method which is a simple process, easy to scale-up and of low cost. We also used the same method for the preparation different new materials [40]. Moreover, attempts were also made to prepare doubly doped $\mathrm{CeO}_{2}$ containing both $\mathrm{Mg}$ and $\mathrm{Zr}$ cations with nominal compositions $\mathrm{Ce}_{1-\mathrm{x}-\mathrm{y}} \mathrm{Mg}_{\mathrm{x}} \mathrm{Zr}_{\mathrm{y}} \mathrm{O}_{2-\delta}(\mathrm{x}=0.05, \mathrm{y}=0.05, \delta=$ oxygen deficiency) for the first time using this method.

\section{Experimental}

Reagent grade chemicals were used throughout the synthesis of the materials. Cerium nitrate was mixed with glycerin in a beaker with mole ratio of cerium to glycerin 1:2. The resulting mixture was heated at $120^{\circ} \mathrm{C}$ in an oven. During this heating process the cerium nitrate reacts with glycerin with the evolution of $\mathrm{NO}_{\mathrm{x}}, \mathrm{CO}_{2}$ and water vapor [41] and led to the formation of foamy precursor. This precursor was calcined in a muffle furnace at temperature ranging from $200^{\circ} \mathrm{C}$ to $800^{\circ} \mathrm{C}$ in steps of $100^{\circ} \mathrm{C}$ for 6 hours in each case to get the desired products. To prepare $\mathrm{CeO}_{2}$ doped with both $\mathrm{Mg}$ and $\mathrm{Zr}$, corresponding metal nitrates with required stoichiometric ratio were mixed in glycerin in such a proportion that mole ratio of total metal ions to glycerin remains about 1:2. Then the same procedure was followed as mentioned above for calcinations. 
The samples were characterized using different techniques such as X-ray powder diffraction (XRD), FTIR spectroscopy, scanning electron microscopy (SEM) and energy dispersive X-ray spectroscopy (EDX). XRD data of the prepared samples were recorded with a Philips PW-1830 X-ray generator in an XDC-700 Guinier Hagg focusing camera (Operating Voltage and Current $40 \mathrm{kV}$ and $30 \mathrm{~mA}$ respectively ) using $\mathrm{CuK} \alpha_{1}$ radiation $(\lambda$ $=1.540598 \AA$ ). The XRD were recorded in an image plate which was scanned using HDCR 35 NDT/ CR 35 NDT scanner. IR absorption spectra were taken on a Perkin-Elmer FTIR spectrometer. For the IR spectroscopic measurements $1.0 \mathrm{mg}$ of the finely ground sample was dispersed into $199 \mathrm{mg} \mathrm{KBr}$ and pressed into a pellet (13 mm diameter). The spectrum of a pure $\mathrm{KBr}$ pellet prepared in the same way was used as a reference. Spectra are given in absorbance units $\left(-\log \left(I / I_{0}\right)\right.$, where $I_{0}, I$ are transmitted intensities through "reference" and "reference + sample", respectively). SEM images and EDX spectra were recorded using JEOL analytical scanning electron microscope (model JSM-6490LA).

\section{Results and Discussions}

\subsection{Characterization of $\mathrm{CeO}_{2}$}

\subsubsection{XRD analysis}

The XRD patterns of the resulting products obtained after heating the organic precursor of $\mathrm{CeO}_{2}$ at different temperatures are shown in Fig. 1. All the lines in the XRD patterns could be perfectly indexed as fluorite type cubic crystal structure of $\mathrm{CeO}_{2}$. In addition, the diffraction peaks only become sharper (Fig. 1) with increasing calcination temperature, which reveals the change in crystallite size with calcination temperature. The lattice parameters of the products were calculated using the program Win Xpow and are listed in Table 1 . The calculated lattice parameters fit very well with the reported literature values.

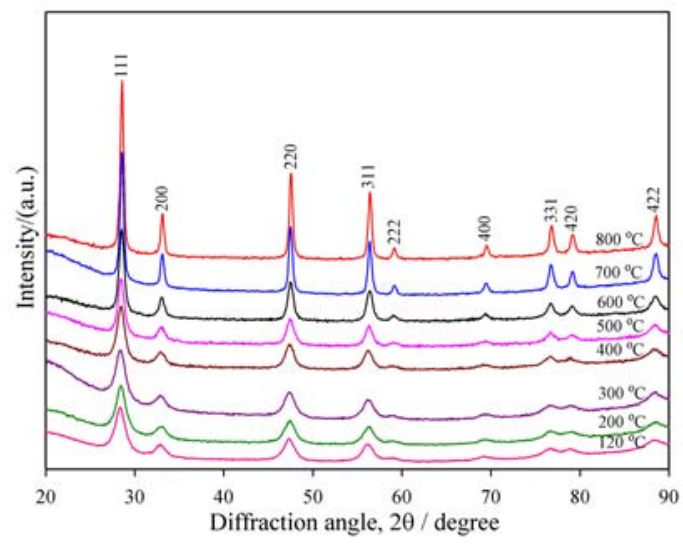

Fig.1. XRD patterns of the resulting product obtained after heating the precursor at different temperature. The diffraction patterns are shifted vertically and $2 \theta$ is shown from $20^{\circ}$ for the sake of clarity. 
From XRD patterns crystallite sizes were calculated using Scherrer equation and listed in Table 1 . It is clearly revealed that with increase in calcination temperature crystallite size increases. The crystallite sizes of $\mathrm{CeO}_{2}$ prepared in the range of $200-800^{\circ} \mathrm{C}$ are in the range of nanoscale. The low temperature $\left(\sim 200^{\circ} \mathrm{C}\right)$ formation of $\mathrm{CeO}_{2}$ allows one to tailor the crystallite sizes in a high range of temperatures.

Table1. Calculated crystallite size of cerium (IV) oxide obtained after heating the precursor at different temperature using Scherrer equation.

\begin{tabular}{ccc}
\hline Calcination temperature $\left({ }^{\circ} \mathrm{C}\right)$ & Lattice parameter, a / & Crystallite size $(\mathrm{nm})$ \\
\hline 200 & $5.414(9)$ & 13 \\
300 & $5.411(8)$ & 14 \\
400 & $5.414(6)$ & 15 \\
500 & $5.412(7)$ & 17 \\
600 & $5.413(7)$ & 19 \\
700 & $5.414(6)$ & 22 \\
800 & $5.413(4)$ & 27 \\
\hline
\end{tabular}

*Standard deviations of lattice parameters are given in parenthesis.

The crystallite coarsening behaviors of the glycerin-nitrate based precursor derived $\mathrm{CeO}_{2}$ has been studied up to $800^{\circ} \mathrm{C}$ and the results are graphically shown in Fig. 2. It can be seen that crystallite sizes exponentially increases with increasing calcination temperature, which indicates the crystalline coarsening process is related to diffusion [42]. Crystallite growth kinetic generally follows the empirical equation [43]: $D^{n}-D_{0}{ }^{n}=k t$. where, $D$ is the mean crystallite size at the time $t, D_{0}$ is the average initial crystallite size, $n$ is the kinetic crystallite growth exponent which, can assume an integer value ranging from 1 to 4 depending upon various kinetic aspects in the coarsening process and $k$ is a temperature dependent rate parameter.

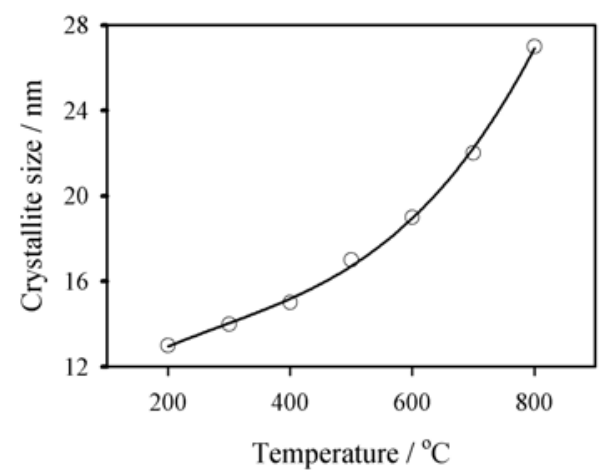

Fig. 2. Crystallite sizes of $\mathrm{CeO}_{2}$ as a function of calcination temperature.

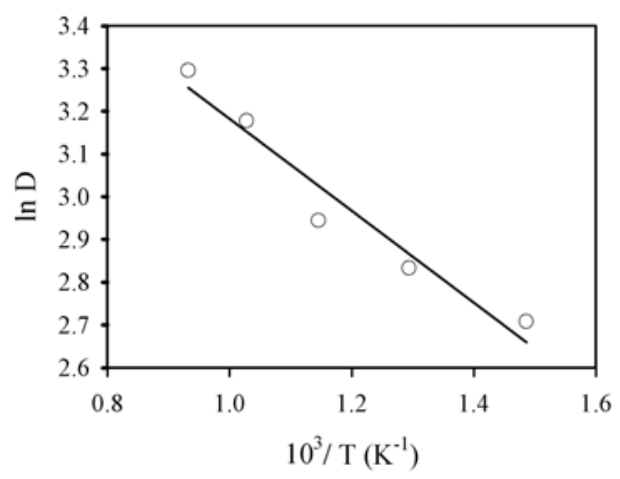

Fig. 3. A plot of $\ln D$ against reciprocal temperature for calculating apparent $\mathrm{E}_{\mathrm{a}}$ 
The apparent activation energy, $E_{a}$ for a crystalline growth process can be calculated using the relation, $k=A \exp \left(-E_{a} / R T\right)$, where $A$ is a constant, $R$ is the gas constant and $T$ is the absolute temperature. For $D>>D_{0}$ and a constant crystallite growth time $t$, which is here the time required for a complete crystallite growth at a given temperature, the slope of the plot of $\ln D$ against $1 / T$ is equal to $-E_{\mathrm{a}} / n R$. Considering $D_{0}$ as crystallite size at $200^{\circ} \mathrm{C}$, it is found that the coarsening of $\mathrm{CeO}_{2}$ powder follows the cubic law $(\mathrm{n}=3)$. Fig. 3 shows the Arrhenius plot constructed from the data given in Table 1 for $\mathrm{CeO}_{2}$, in which $\ln D$ is plotted as a function of $1 / T$. The values of the apparent activation energy $E_{a}$ for crystallite growth are calculated from the slope of the lines and value of $n$. The apparent activation energy for crystallite growth of $\mathrm{CeO}_{2}$ found in this work is $26.8 \mathrm{kJmol}^{-1}$, which is much lower value compared to reported for the $\mathrm{CeO}_{2}$ prepared via thermal decomposition of ammonium ceric nitrate $\left(65 \mathrm{kJmol}^{-1}\right)$ [44], carbonate precipitate $(68.7$ $\left.\mathrm{kJmol}^{-1}\right)$ [42], cerous oxalate $\left(125 \mathrm{kJmol}^{-1}\right)$ [44], cerous nitrate (203 and $\left.46 \mathrm{kJmol}^{-1}\right)$ [44], and hydrated cerium oxides (157 and $231 \mathrm{kJmol}^{-1}$ ) [45]. This phenomenon reveals that the crystallite coarsening behavior and mechanism are precursor dependent. And such a low value $\left(26.8 \mathrm{kJmol}^{-1}\right)$ of apparent activation energy for coarsening of $\mathrm{CeO}_{2}$ found in the present study indicates that cation transport is likely surface-diffusion related as reported for thermal decomposition of carbonate-precipitate [42].

\subsubsection{Scanning electron microscopy (SEM)}

SEM images of two selected samples are given in Fig. 4, which shows those particles are spherical in shape and sizes are in the range of nanoscale $(<100 \mathrm{~nm})$, a morphology more suitable to consolidation and ceramic fabrication [42]. Thus, from XRD analysis and SEM image, formation of nanocrysralline $\mathrm{CeO}_{2}$ was confirmed.
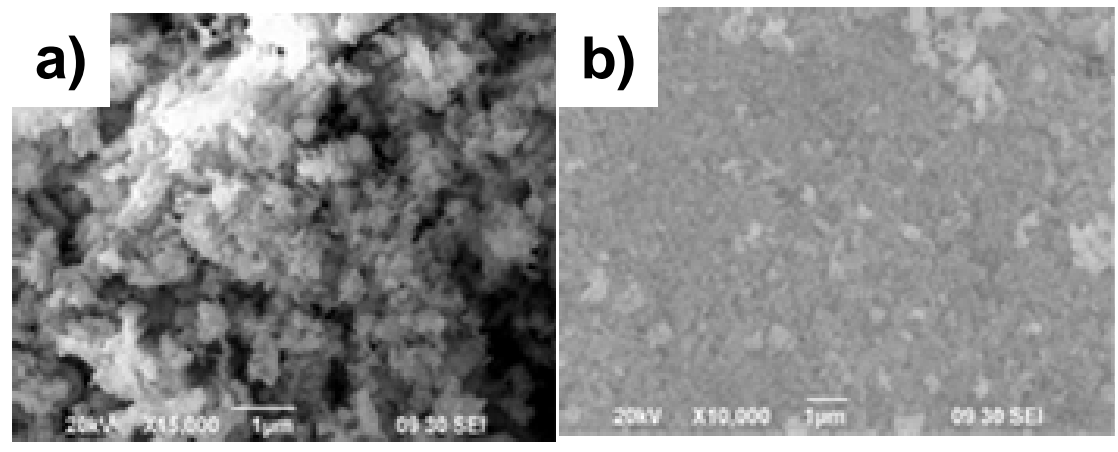

Fig. 4. SEM images of the $\mathrm{CeO}_{2}$ obtained after heating the precursor at (a) $800^{\circ} \mathrm{C}$ and (d) $500^{\circ} \mathrm{C}$ temperature. 
3.2. Characterization of $C e_{1-x} D_{x} O_{2-\delta}(D=M g, Z r$ and $x=0.10)$ and $C e_{1-x-y} M g_{x} Z r_{y} O_{2-\delta}$ $(x=0.05, y=0.05)$

\subsubsection{XRD analysis}

The XRD patterns of $\mathrm{Mg}$ doped $\mathrm{CeO}_{2}, \mathrm{Zr}$ doped $\mathrm{CeO}_{2}$ as well as both $\mathrm{Mg}$ and $\mathrm{Zr}$ doped $\mathrm{CeO}_{2}$ are shown in Fig. 5. There exists exactly equal number of lines as in powder pattern of $\mathrm{CeO}_{2}$, which indicates the incorporation of both $\mathrm{Mg}$ and $\mathrm{Zr}$ in $\mathrm{CeO}_{2}$ lattice.

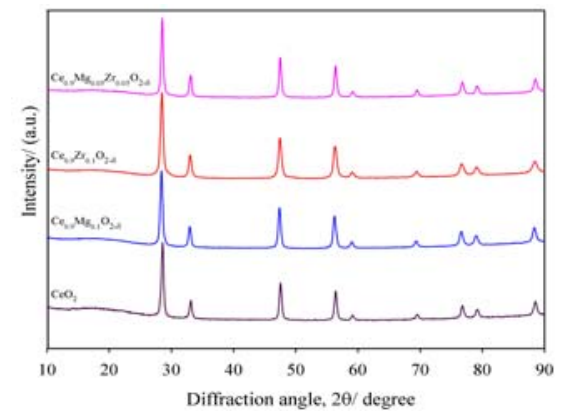

Fig. 5. XRD patterns of $\mathrm{Ce}_{1-\mathrm{x}} \mathrm{D}_{\mathrm{x}} \mathrm{O}_{2-\delta}(\mathrm{D}=\mathrm{Mg}, \mathrm{Zr}$ and $\mathrm{x}=0.10)$ and $\mathrm{Ce}_{1-\mathrm{x}-\mathrm{y}} \mathrm{Mg}_{\mathrm{x}} \mathrm{Zr}_{\mathrm{y}} \mathrm{O}_{2-\delta}(\mathrm{x}=0.05, \mathrm{y}=$ 0.05 ). The diffraction patterns are shifted vertically and $2 \theta$ is shown from $10^{\circ}$ for the sake of clarity

There is no significant change in peak positions and relative intensities of XRD lines for doped samples which ensure the retainment of fluorite crystal structure. XRD patterns of these compounds indicate successful doping of $\mathrm{Mg}$ and $\mathrm{Zr}$ in $\mathrm{CeO}_{2}$ lattice and the doping level is upto $10 \%$, which has been observed for related system with different dopants [16, 23-28]. The crystallite sizes of these doped samples were calculated using Scherrer equation which revealed that $\mathrm{Mg}$ and $\mathrm{Zr}$ doped ceria prepared at $800^{\circ} \mathrm{C}$ posses crystallite sizes in the range of $22-26 \mathrm{~nm}$.

\subsubsection{EDX spectroscopy}

The presence of doped elements $(\mathrm{Mg}, \mathrm{Zr})$ were confirmed by EDX. EDX spectrum of sample with nominal composition $\mathrm{Ce}_{1-\mathrm{x}-\mathrm{y}} \mathrm{Mg}_{\mathrm{x}} \mathrm{Zr}_{\mathrm{y}} \mathrm{O}_{2-\delta}(\mathrm{x}=0.05, \mathrm{y}=0.05)$ is shown in Fig. 6. In the spectrum, the peaks are identified as $\mathrm{O}(\mathrm{K}), \mathrm{Mg}(\mathrm{K}), \mathrm{Zr}(\mathrm{L})$ and $\mathrm{Ce}(\mathrm{L})$ at respective positions, which indicates successful doping of both $\mathrm{Mg}$ and $\mathrm{Zr}$ in $\mathrm{CeO}_{2}$.

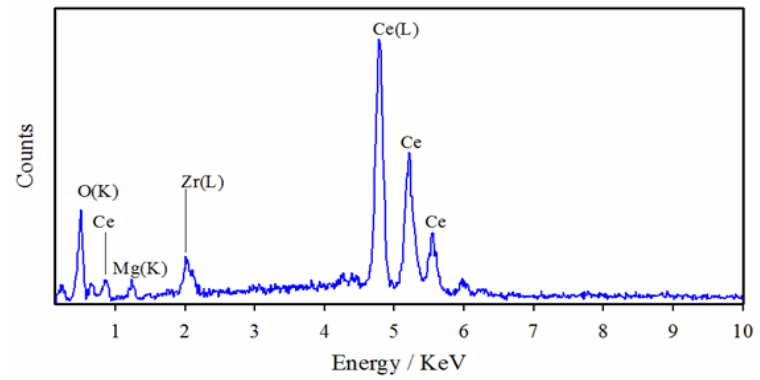

Fig. 6. EDX spectra of $\mathrm{Ce}_{0.9} \mathrm{Mg}_{0.05} \mathrm{Zr}_{0.05} \mathrm{O}_{2-\delta}$ 


\subsubsection{FTIR spectrum analysis}

FTIR absorption spectrum of $\mathrm{Ce}_{1-\mathrm{x}} \mathrm{D}_{\mathrm{x}} \mathrm{O}_{2-\delta}(\mathrm{D}=\mathrm{Mg}, \mathrm{Zr}$ and $\mathrm{x}=0.10)$ and $\mathrm{Ce}_{1-\mathrm{x}-\mathrm{y}} \mathrm{Mg}_{\mathrm{x}} \mathrm{Zr}_{\mathrm{y}} \mathrm{O}_{2-}$ ${ }_{\delta}(\mathrm{x}=0.05, \mathrm{y}=0.05)$ are shown in Fig. 7 .

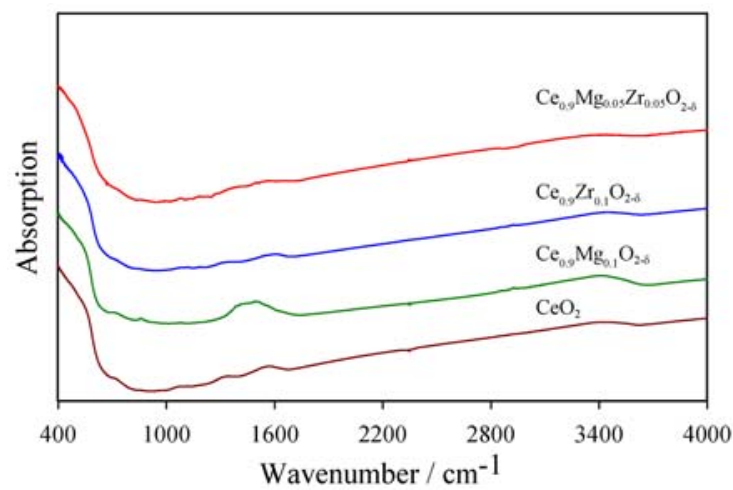

Fig. 7. FTIR absorption spectrum of products (as denoted) prepared at $800^{\circ} \mathrm{C}$ and measured in the range of $400 \mathrm{~cm}^{-1}-4000 \mathrm{~cm}^{-1}$.

The strong band below $700 \mathrm{~cm}^{-1}$ wavenumber can be assigned as $\mathrm{Ce}-\mathrm{O}$ vibration. The spectra shows presence of two broad bands at band at $1569 \mathrm{~cm}^{-1}$ and $3435 \mathrm{~cm}^{-1}$ for $\mathrm{Ce}_{0.9} \mathrm{Mg}_{0.1} \mathrm{O}_{2-\delta}$ which is related to $\mathrm{H}-\mathrm{O}-\mathrm{H}$ bending and $\mathrm{O}-\mathrm{H}$ stretching mode of vibration of water. The source of these bands can be described considering the surface absorption of atmospheric moisture by rare earth $\mathrm{Mg}$ doped ceria. The amount of absorption increases with the increase in surface area, which is directly related to the decrease in particle size. The XRD data shows that $\mathrm{Ce}_{0.9} \mathrm{Mg}_{0.1} \mathrm{O}_{2-\delta}$ has lowest crystallite size among $\mathrm{Ce}_{0.9} \mathrm{Mg}_{0.1} \mathrm{O}_{2-\delta}$, $\mathrm{Ce}_{0.9} \mathrm{Zr}_{0.1} \mathrm{O}_{2-\delta}$ and $\mathrm{Ce}_{0.9} \mathrm{Mg}_{0.05} \mathrm{Zr}_{0.05} \mathrm{O}_{2-\delta}$ so, have higher surface area and would show higher absorption of moisture from air.

\section{Conclusion}

Nanocrystalline $\mathrm{CeO}_{2}$ were prepared using glycerin nitrate method, where the precursor obtained from the mixture of cerium nitrate and glycerin were calcined at temperatures ranging from $200^{\circ} \mathrm{C}$ to $800^{\circ} \mathrm{C}$ in steps of $100^{\circ} \mathrm{C}$ in a muffle furnace. The XRD study reveals that the structure of the system is fluorite type. Crystallite size were calculated using Scherrer equation and shows that crystallite size increases systematically with increasing calcination temperature and all the calcined product belongs to nanocrystal. SEM images also confirm the formation of nanocrystalline ceria. The size of the crystallites can be easily monitored by acting on annealing temperature. The apparent activation energy for crystalline coarsening is found to be very low $\left(26.8 \mathrm{kJmol}^{-1}\right)$ for this precursor compared to reported data. Using the same method, doubly doped $\mathrm{CeO}_{2}$ containing both 
$\mathrm{Mg}$ and $\mathrm{Zr}$ has been prepared for the first time. EDX analysis confirms the presence of both dopants $(\mathrm{Mg}$ and $\mathrm{Zr}$ ) in ceria. For doping level upto 5\% $\mathrm{Mg}$ and $5 \% \mathrm{Zr}$ products show fluorite type cubic crystal structure with no extra line on their XRD patterns. Crystallite size of doubly doped compounds also belongs to nanoscale.

\section{Acknowledgment}

The authors acknowledge S.N. Bose Centre of University of Dhaka and Higher Education Quality Enhancement Project (HEQEP - CP 231) for financial support.

\section{References}

1. S. Tsunekawa, R. Sahara, Y. Kawazoe, and A. Kasuya, Mater. Trans. JIM 41, 1104 (2000). http://dx.doi.org/10.2320/matertrans1989.41.1104

2. E. Bekyarova, P. Fornasiero, J. Kaspar, and M. Graziani, Catal. Today 45, 179 (1998). http://dx.doi.org/10.1016/S0920-5861(98)00212-0

3. H. Yahiro, Y. Baba, K. Eguchi, and H. Arai, J. Electrochem. Soc. 135, 2077 (1988). http://dx.doi.org/10.1149/1.2096212

4. N. Izu, W. Shin, N. Murayama, and S. Kanzaki, Sens. Actuator B: Chem. 87, 95 (2002). http://dx.doi.org/10.1016/S0925-4005(02)00224-1

5. M. Lira-Cantu and F. C. Krebs, Sol. Energy Mater. Sol. Cells 90, 2076 (2006). http://dx.doi.org/10.1016/j.solmat.2006.02.007

6. M. Flytzani-Stephanopoulos, M. Sakbodin, and Z. Wang, Science 312, 1508 (2006). http://dx.doi.org/10.1126/science.1125684

7. A. H. Morshed, M. E. Moussa, S. M. Bedair, R. Leonard, S. X. Liu, and N. El-Masry, Appl. Phys. Lett. 70, 1647 (1997). http://dx.doi.org/10.1063/1.118658

8. N. Kakuta, N. Morishima, M. Kotobuki, T. Iwase, T. Mizushima, Y. Sato, and S. Matsuura, Appl. Surf. Sci. 121, 408 (1997). http://dx.doi.org/10.1016/S0169-4332(97)00346-2

9. A. Trovarelli, C. Leitenburg, M. Boaro, and G. Dolcetti, Catal. Today 50, 353 (1999). http://dx.doi.org/10.1016/S0920-5861(98)00515-X

10. Z. Yang, T. K. Woo, and K. Hermansson, J. Chem. Phys. 124, 224704 (2006). http://dx.doi.org/10.1063/1.2200354

11. T. Masui and N. Imanaka, Mater. Integr. 16, 29 (2003).

12. D. Widmann, R. Leppelt, and R. J. Behm, J. Catal. 251, 437 (2007). http://dx.doi.org/10.1016/j.jcat.2007.07.026

13. V. Shapovalov and H. Metiu, J. Catal. 245, 205 (2007). http://dx.doi.org/10.1016/j.jcat.2006.10.009

14. M. Mogensen, N. M. Sammes, and G. A. Tompsett, Solid State Ionics 129, 63 (2000). http://dx.doi.org/10.1016/S0167-2738(99)00318-5

15. Y. Zhang, S. Andersson, and M. Muhammed, Appl. Catal. B: Environ. 6, 325 (1995). http://dx.doi.org/10.1016/0926-3373(95)00041-0

16. A. E. C. Palmqvist, E. M. Johansson, S. G. Järås, and M. Muhammed, Catal. lett. 56, 69 (1998). http://dx.doi.org/10.1023/A:1019032306894

17. Y. Izumi, Y. Iwata, and K. Aika, J. Phys. Chem. 100, 9421 (1996). http://dx.doi.org/10.1021/jp952602o

18. A. A. Kais, A. Bennani, C. F. Aissi, G. Wrobel, and M. Guelton, J. Chem. Soc. Faraday transitions 88, 1321 (1992).

19. P. Knauth, G. Schwitzgebel, A. Tschöpe, and S. Villain, J. Solid State Chem. 140, 295 (1998). http://dx.doi.org/10.1006/jssc.1998.7890

20. Y. M. Chiang, E. B. Lavik, and D. A. Blom, Nanostructured mater. 9, 633 (1997). http://dx.doi.org/10.1016/S0965-9773(97)00142-6 
21. M. I. Zaki, G. A. M. Hussein, S. A. Mansour, and H. A. El-Ammawy, J. Molecular Catal. 51, 209 (1989). http://dx.doi.org/10.1016/0304-5102(89)80101-4

22. C. Leitenburg, D. Goi, A. Primavera, A. Trovarelli, and G. Dolcetti, Appl. Catal. B: Environ. 11, L29 (1996). http://dx.doi.org/10.1016/S0926-3373(96)00080-X

23. J. V. Herle, T. Horita, T. Kawada, N. Sakai, H. Yokokawa, and M. Dokiya, Ceram. Int. 24, 229 (1998). http://dx.doi.org/10.1016/S0272-8842(97)00007-2

24. R. L. Jones, Surf. Coat. Technol. 86, 127 (1996). http://dx.doi.org/10.1016/S02578972(96)03007-1

25. D. Y. Wang and A. S. Nowick, J. Solid State Chem. 35, 325 (1980). http://dx.doi.org/10.1016/0022-4596(80)90529-0

26. J. A. Allemann, B. Michel, H. B. Märki, L. J. Gauckler, and E. M. Moser, J. Eur. Ceram. Soc. 15, 951 (1995). http://dx.doi.org/10.1016/0955-2219(95)00073-4

27. J. G. Nunan, M. J. Cohn, and J. T. Donner, Catal. today 14, 277 (1992). http://dx.doi.org/10.1016/0920-5861(92)80029-M

28. G. Gritzner and P. Steger, J. Eur. Ceram. Soc. 12, 461 (1993). http://dx.doi.org/10.1016/09552219(93)90080-B

29. A. Makishima, H. Kubo, K. Wada, Y. Kitami, and T. Shimohira, J. Am. Ceram. Soc. 69, C127 (1986).

30. Y. Hakuta, S. Onai, H. Terayama, T. Adschiri, and K. Arai, J. Mater. Sci. Lett. 17, 1211 (1998). http://dx.doi.org/10.1023/A:1006597828280

31. N. C. Wu, E. W. Shi, Y. Q. Zheng, and W. J. Li, J. Am. Ceram. Soc. 85, 2462 (2002). http://dx.doi.org/10.1111/j.1151-2916.2002.tb00481.x

32. T. Masui, K. Fujiwara, K. Machida, G. Adachi, T. Sakata, and H. Mori, Chem. Mater. 9, 2197 (1997). http://dx.doi.org/10.1021/cm970359v

33. X. D. Zhou, W. Huebner, and H. U. Anderson, Appl. Phys. Lett. 80, 3814 (2002). http://dx.doi.org/10.1063/1.1481244

34. P. L. Chen and I. W. Chen, J. Am. Ceram. Soc. 76, 1577 (1993). http://dx.doi.org/10.1111/j.1151-2916.1993.tb03942.x

35. F. Bondioli, A. B. Corradi, T. Manfredini, G. Leonelli, and R. Bertoncello, Chem. Mater. 12, 324 (2000). http://dx.doi.org/10.1021/cm990128j

36. F. Gao, Q. Lu, and S. Komarneni, J. Nanosci. Nanotechnol. 6, 3812 (2006). http://dx.doi.org/10.1166/jnn.2006.609

37. R. J. Qi, Y. J. Zhu, and Y. H. Huang, Nanotechnol. 16, 2502 (2005). http://dx.doi.org/10.1088/0957-4484/16/11/006

38. Y. Wang, T. Mori, J. Li, and T. Ikegami, J. Am. Ceram. Soc. 85, 3105 (2002). http://dx.doi.org/10.1111/j.1151-2916.2002.tb00591.x

39. E. L. Navarrete, A. Caballero, A. R. G. Elipe, and M. Ocana, J. Mater. Res. 17, 797 (2002). http://dx.doi.org/10.1557/JMR.2002.0117

40. T. Debnath, C. H. Rüscher, P. Fielitz, S. Ohmann, and G. Borchardt, J. Solid State Chem. 183, 2582 (2010). http://dx.doi.org/10.1016/j.jssc.2010.07.019

41. K. T. Pillai, R. V. Kamat, V. N. Vaidya, and D. D. Sood, Mater. Chem. Phys. 44, 255 (1996). http://dx.doi.org/10.1016/0254-0584(96)80065-4

42. J. Li, T. Ikegami, Y. Wang, and T. Mori, J. Solid State Chem. 168, 52 (2002). http://dx.doi.org/10.1006/jssc.2002.9678

43. R. J. Brook, Ceramic Fabrication Processes Edited by F. F. Y. Wang, (Academic Press, New York, pp. 235.

44. K. A. El-Adham and A. M. M. Gadalla, Inter. ceram. 3, 223 (1977).

45. N. Audebrand, J. P. Auffredic, and D. Louer, Chem. Mater. 12, 1791 (2000). http://dx.doi.org/10.1021/cm001013e 